\title{
Day and Night Seasonal Temperature Differences for a Naturally Ventilated Freestall Barn with Different Stocking Densities
}

\author{
A. M. Wagner-Storch and R. W. Palmer \\ Department of Dairy Science, 1675 Observatory Dr., \\ University of Wisconsin, \\ Madison 53706
}

\section{ABSTRACT}

Temperature data were collected during three 28-d periods. Cold-season one-side-occupied (CSOO), warmseason two-sides-occupied (WSTO), and cold-season two-sides-occupied (CSTO) were used to determine day and night freestall barn temperature differences between north-side and south-side, east-end and westend, and inside to outside of a naturally ventilated, curtain sided, noninsulated barn. Five sensors measured temperature every 15 min for 28-d periods beginning November 30, 2000, July 9, 2001, and December 23,2001 . Stocking densities were 90 to $100 \%$ for CSOO south-side and $0 \%$ for CSOO north-side; 92 to $108 \%$ for WSTO south-side and 46 to $74 \%$ for WSTO north-side; and 102 to $116 \%$ for CSTO south-side and 64 to $86 \%$ for CSTO north-side. Mean day temperatures (MDT) and mean night temperatures (MNT) were different for all within barn comparisons. Inside and outside MDT were different for cold-season periods. MDT differences between inside and outside were $\operatorname{CSTO}\left(6.27^{\circ} \mathrm{F}\right)>$ $\operatorname{CSOO}\left(5.64^{\circ} \mathrm{F}\right)>\mathrm{WSTO}\left(-0.03^{\circ} \mathrm{F}\right)$. MNT differences between inside and outside were $\mathrm{CSTO}\left(7.14^{\circ} \mathrm{F}\right)>\mathrm{CSOO}$ $\left(5.76^{\circ} \mathrm{F}\right)>$ WSTO $\left(1.32^{\circ} \mathrm{F}\right)$. Absence of animals on one side of the barn during cold seasons decreased the average temperature difference between inside and outside approximately $1^{\circ} \mathrm{F}$ (day $0.63^{\circ} \mathrm{F}$, night $1.38^{\circ} \mathrm{F}$ ). Southside MDT and MNT were higher than the north-side for CSOO. MDT differences between north-side and southside were $\operatorname{CSOO}\left(-2.71^{\circ} \mathrm{F}\right)>\operatorname{CSTO}\left(-1.22^{\circ} \mathrm{F}\right)>$ WSTO $\left(-0.36^{\circ} \mathrm{F}\right)$. MNT differences between north-side and south-side were $\operatorname{CSOO}\left(-2.46^{\circ} \mathrm{F}\right)>\operatorname{CSTO}\left(-1.06^{\circ} \mathrm{F}\right)>$ WSTO $\left(-0.49^{\circ} \mathrm{F}\right)$. The average temperature difference for the unoccupied side during cold seasons was almost $1.5^{\circ} \mathrm{F}$ lower throughout the day than the fully stocked side (day $1.49^{\circ} \mathrm{F}$, night $1.40^{\circ} \mathrm{F}$ ). Stocking density was thought to be the major cause of differences between north-side and south-side. East-end and west-end mean

Received May 14, 2002.

Accepted July 8, 2002.

Corresponding author: R. W. Palmer; e-mail: rwpalmer@facstaff. wisc.edu. temperatures were not different across seasons, therefore, future barn-temperature research with barns of similar characteristics may require only one sensor per side.

(Key words: freestall barn, natural ventilation, stocking density, temperature)

Abbreviation key: $\mathbf{C S O O}=$ cold-season one-side-occupied, CSTO = cold-season two-sides-occupied, MDT = mean day temperature, MNT = mean night temperature, $\mathbf{R H}=$ relative humidity, $\mathbf{W S T O}=$ warm-season two-sides-occupied.

\section{INTRODUCTION}

Climate variation in the Midwest region of the U.S. affects the temperature and relative humidity (RH\%) variation within freestall barns and between inside and outside of the barn. The degree of difference can be attributed to some or all of the following factors: outside temperature differences, freestall barn size and construction material type, presence or absence of insulation, enclosed or open sidewalls, stocking density, sidewall height and amount of curtain openings. Ventilation in a freestall barn affects the temperature, maintains lower moisture levels inside the barns (Bickert and Stowell, 1993), and aids in maintaining a comfortable environment for dairy cattle. Previous research, which measured inside and outside temperature, involved a wide variety of different freestall barn types. Janni (1998) compared an insulated four-row tail-to-tail barn with $118 \%$ stocking rate to an uninsulated three-row barn with a $109 \%$ stocking rate. Stowell and Bickert (1994) compared 16 barns of different types (seven four-row, four six-row, and five narrow), different orientations (ten N-S, five E-W and one NE-SW), different insulation levels (two insulated and 14 uninsulated), and with different stocking rates (61 to 121\%). Other literature failed to specify barn design and stocking rate information.

Cold season (winter weather conditions) affects temperature and $\mathrm{RH} \%$ variation. Previous research had found temperature differences between inside and outside of cold, naturally ventilated freestall barns to be 
approximately 5.4 to $10.8^{\circ} \mathrm{F}$ (Kammel et al., 1982; Bickert and Stowell, 1993; Cooper et al., 1998). Insulated barns showed a temperature difference of approximately 9 to $21.6^{\circ} \mathrm{F}$ (Kammel et al., 1982; Janni, 1998). Janni (1998) studied north to south temperature variation within the insulated freestall barns during a cold season and found temperature differences ranging from 0.72 to $1.8^{\circ} \mathrm{F}$.

The $\mathrm{RH} \%$ variation during cold season was different for insulated and enclosed vs. noninsulated and open barns. Arave et al. (1994) and Janni (1998) found insulated and enclosed barns had a $\mathrm{RH} \%$ range of 49.1 to $98 \%$, which was smaller than noninsulated and open barns' $\mathrm{RH} \%$ range of 41.8 to $100 \%$.

Warm season (summer-weather conditions) also affects temperature and $\mathrm{RH} \%$ variation in freestall barns. Janni (1999) found a noninsulated freestall barn's temperature range, from the inside to the outside, was -0.72 to $2.16^{\circ} \mathrm{F}$, and an insulated barn's temperature range was 0.36 to $4.32^{\circ} \mathrm{F}$. Janni (1999) also found north to south temperature variation within the insulated freestall barn, which ranged from -0.36 to $0.36^{\circ} \mathrm{F}$. Stowell and Bickert (1994) found temperature variation within a noninsulated barn of approximately $1.40^{\circ} \mathrm{F}$.

Janni (1999) found RH\% variation during the warm season was similar for insulated and noninsulated barns. The insulated barn had an inside $\mathrm{RH} \%$ range of 64 to 85 and an outside $\mathrm{RH} \%$ range of 59 to 71 . The noninsulated barn had an inside $\mathrm{RH} \%$ range of 67 to $87 \%$ and an outside $\mathrm{RH} \%$ range of 63 to 74 (Janni, 1999).

Previous studies have shown that temperature and $\mathrm{RH} \%$ variation and the degree of variation are different when comparing warm vs. cold seasons and physical characteristics of a barn. Stowell and Bickert (1994) found that completely open sidewalls provide additional cooling compared with partially open sidewalls. The objectives of this study were 1) to develop a methodology to conduct temperature differentiation studies in freestall barns; 2) to determine the effect of stocking rate on internal barn temperature; and 3) to determine the temperature variation and difference in the University of Wisconsin Arlington freestall barn for WSTO, CSTO, and CSOO, for the following comparisons: north-side vs. south-side, east-end vs. west-end and inside vs. outside $\times$ time of day.

\section{MATERIALS AND METHODS}

The freestall barn used for this study is located in Arlington, Wisconsin, U.S. It is four-row, tail-to-tail, 104-stall, noninsulated barn with east to west orientation. The dimensions are $100 \mathrm{ft}$ wide, $120 \mathrm{ft}$ long, with ten 12 -ft bays, 12 -ft eave sidewall height, and a roof pitch of 4/12. The barn has a wood frame and is supported by 6 in. $\times 6$ in. wood upright posts, located at the feed alley and at the front of the internal row of stalls. Ventilation is controlled by a 6.5 -in. eve opening and 9-ft adjustable curtains. No fans or sprinklers were used in the barn. Research protocols insured animal care guideline compliance.

Four HOBO (Onset Computer Corporation, Pocasset, MA) H8 Pro Series sensors were located at the SW, SE, $\mathrm{NW}$, and NE sections of the barn, approximately $30 \mathrm{ft}$ from the ends of the barn and $4 \mathrm{ft}$ above the tops of the stalls. A fifth HOBO sensor was located in a radiation shield outside the barn on the north side, $15 \mathrm{ft}$ from the barn and $2.5 \mathrm{ft}$ off the ground. Sensors were set to record temperature data at 15 -min intervals. Data were downloaded from the sensors at the barn via a HOBO Shuttle.

Data were collected for three 28 -d periods. The south side of the barn had 50 stalls, and the north side had 54 stalls. Cold-season one-side-occupied (CSOO) data were collected from November 30 to December 27, 2000, and had 45 to 50 cows present on the south-side of the barn and no cows on the north-side. Cows on the southside were milked with a conventional double- 6 herringbone parlor and cows on the north-side were milked with a robotic milker. Stocking densities increased over time as the herd grew. The herd management objective was to keep stocking density on the south side in the 100 to $110 \%$ range and the number of animals on the north side at a lower level to minimize training of animals to use the robotic milker. No cows were housed on the north-side for the CSOO period while the robotic milker was being installed. Warm-season two-sides-occupied (WSTO) data were collected from July 9 to Aug 5,2001 , and had 46 to 54 cows present on the southside and 23 to 37 cows present on the north-side. Coldseason two-sides-occupied (CSTO) data were collected from Dec 23, 2001 to Jan 19, 2002, and had 51 to 58 cows present on the south-side and 32 to 43 cows present on the north-side.

Time of day was classified as the following: day (12 p.m. to 6 p.m.) and night (12 a.m. to 6 a.m.). Day and night definitions and identification of the locations allowed for analysis of the following mean comparisons for WSTO, CSTO, and CSOO, respectively:

Location: Inside vs. Outside of the barn $\times$ time of day

Barn location: NE vs. NW vs. SE vs. SW $\times$ time of day

Barn Side: North-side vs. South-side $\times$ time of day

Barn End: East-end vs. West-end $\times$ time of day

Seasonal differences for inside vs. outside, north-side vs. south-side, and east-end vs. west-end, $\times$ time of day

Inside vs. outside, north-side vs. south-side, and eastend vs. west-end, comparisons were chosen to determine the effects of barn orientation and physical charac- 
Table 1. Mean $( \pm \mathrm{SE})$ temperature $\left({ }^{\circ} \mathrm{F}\right)$ by period for location and time of day. ${ }^{1}$

\begin{tabular}{lllr}
\hline $\begin{array}{l}\text { Location and } \\
\text { time of day }\end{array}$ & WSTO & CSTO & CSOO \\
\hline Inside day & $82.09 \pm 0.09^{\mathrm{a}}$ & $30.21 \pm 0.14^{\mathrm{a}}$ & $19.37 \pm 0.17^{\mathrm{a}}$ \\
Outside day & $82.13 \pm 0.20^{\mathrm{a}}$ & $23.94 \pm 0.36^{\mathrm{b}}$ & $13.50 \pm 0.36^{\mathrm{b}}$ \\
Inside night & $68.46 \pm 0.10^{\mathrm{b}}$ & $25.33 \pm 0.15^{\mathrm{b}}$ & $14.46 \pm 0.18^{\mathrm{b}}$ \\
Outside night & $67.14 \pm 0.21^{\mathrm{c}}$ & $18.19 \pm 0.38^{\mathrm{c}}$ & $8.69 \pm 0.40^{\mathrm{c}}$ \\
\hline \multicolumn{2}{c}{ a,b,c Means within column with different superscripts differ $(P<0.05)}$. & \\
${ }^{1} \mathrm{MDT}$ = mean day temperature, MNT=mean night temperature, WSTO = warm-season two-sides-occupied, \\
CSTO = cold-season two-sides-occupied, CSOO = cold-season one-side-occupied.
\end{tabular}

teristics on temperature variation. Day and night temperature data from all five sensors, for all periods were analyzed with Statistical Analysis Software (SAS) using the MIXED Procedure and lsmeans to determine statistical differences between means. The model statement for each period's analysis included the mean temperature as the dependent variable and sensor location (inside vs. outside, NE vs. NW vs. SE vs. SW, northside vs. south-side, or east-end vs. west-end), time of day (day and night), and the interaction between sensor location and time of day were independent variables. Period comparisons were modeled and tested with the mean difference between sensor locations as the dependent variable and period as the independent variable.

\section{RESULTS AND DISCUSSION}

WSTO day and night temperature ranges were 67.65 to $93.21^{\circ} \mathrm{F}$ and 53.19 to $79.41^{\circ} \mathrm{F}$, respectively, with mean day temperatures (MDT) of $82.10^{\circ} \mathrm{F}$ and mean night temperatures (MNT) of $68.20^{\circ} \mathrm{F}$. CSTO day and night temperature ranges were 1.97 to 55.28 and 0.75 to $43.92^{\circ} \mathrm{F}$, respectively, with MDT of $28.96^{\circ} \mathrm{F}$ and MNT of $23.91^{\circ} \mathrm{F}$. CSOO day and night temperature ranges were -8.68 to $46.10^{\circ} \mathrm{F}$ and -16.71 to $39.48^{\circ} \mathrm{F}$, respectively, with MDT of $18.20^{\circ} \mathrm{F}$ and MNT of $13.31^{\circ} \mathrm{F}$.

MDT and MNT were different $(P<0.05)$ for all within barn comparisons (NE vs. NW vs. SW vs. SE, north- side vs. south-side, east-end vs. west-end) and inside to outside for WSTO (Tables 1, 2, 3, and 4). WSTO inside MNT was $1.32^{\circ} \mathrm{F}$ higher $(P<0.05)$ than MNT outside. CSTO MDT inside was $6.27,4.88$, and $12.02^{\circ} \mathrm{F}$ higher $(P<0.05)$ than MDT outside, MNT inside, and MNT outside, respectively (Table 1 ). MDT outside and MNT inside were approximately 6 to $7^{\circ} \mathrm{F}$ higher $(P<$ $0.05)$ than MNT outside. CSOO MDT inside was 5.87, 4.91 , and $10.68^{\circ} \mathrm{F}$ higher $(P<0.05)$ than MDT outside, MNT inside, and MNT outside, respectively. MDT outside and MNT inside were approximately $5^{\circ} \mathrm{F}$ higher $(P<0.05)$ than the MNT outside.

There was no difference $(P<0.05)$ between the four barn locations during the day for WSTO and CSTO and during the night for WSTO (Table 2). CSTO SW location had about a $2^{\circ} \mathrm{F}$ higher $(P<0.05)$ MNT than NW and $\mathrm{NE}$ locations. This may have been caused by the cooling effect of the prevailing wind. The SE location MNT was not different $(P<0.05)$ than the other three locations. CSOO location temperature results were SW and SE $\mathrm{MDT}>\mathrm{NW}$ and NE MDT $>$ SW and SE MNT $>$ NW and NE MNT $(P<0.05)$.

WSTO and CSTO north and south side MDT and MNT were not different $(P<0.05)$ (Table 3$)$. CSOO results were south-side MDT $>$ north-side MDT $>$ southside MNT $>$ north-side MNT $(P<0.05)$.

East-end and west-end MDT and MNT were not different for all three seasons $(P<0.05)$ (Table 4$)$.

Table 2. Mean $( \pm \mathrm{SE})$ temperature $\left({ }^{\circ} \mathrm{F}\right)$ by period for barn location and time of day. ${ }^{1}$

\begin{tabular}{llll}
\hline $\begin{array}{l}\text { Location and } \\
\text { time of day }\end{array}$ & WSTO & CSTO & CSOO \\
\hline NW day & $81.75 \pm 0.19^{\mathrm{a}}$ & $29.58 \pm 0.28^{\mathrm{a}}$ & $17.94 \pm 0.32^{\mathrm{b}}$ \\
NE day & $82.08 \pm 0.18^{\mathrm{a}}$ & $29.63 \pm 0.29^{\mathrm{a}}$ & $18.08 \pm 0.33^{\mathrm{b}}$ \\
SW day & $82.30 \pm 0.19^{\mathrm{a}}$ & $31.19 \pm 0.28^{\mathrm{a}}$ & $20.89 \pm 0.32^{\mathrm{a}}$ \\
SE day & $82.25 \pm 0.18^{\mathrm{a}}$ & $30.46 \pm 0.30^{\mathrm{a}}$ & $20.55 \pm 0.36^{\mathrm{a}}$ \\
NW night & $68.17 \pm 0.20^{\mathrm{b}}$ & $24.86 \pm 0.30^{\mathrm{c}}$ & $13.21 \pm 0.35^{\mathrm{d}}$ \\
NE night & $68.26 \pm 0.19^{\mathrm{b}}$ & $24.75 \pm 0.30^{\mathrm{c}}$ & $13.25 \pm 0.35^{\mathrm{d}}$ \\
SW night & $68.79 \pm 0.19^{\mathrm{b}}$ & $26.49 \pm 0.29^{\mathrm{b}}$ & $15.93 \pm 0.34^{\mathrm{c}}$ \\
SE night & $68.62 \pm 0.19^{\mathrm{b}}$ & $25.24 \pm 0.31^{\mathrm{bc}}$ & $15.45 \pm 0.38^{\mathrm{c}}$ \\
\hline
\end{tabular}

${ }^{\mathrm{a}, \mathrm{b}, \mathrm{c}}$ Means within column with different superscripts differ $(P<0.05)$.

${ }^{1} \mathrm{MDT}=$ mean day temperature, $\mathrm{MNT}=$ mean night temperature, $\mathrm{WSTO}=$ warm-season two-sides-occupied, $\mathrm{CSTO}=$ cold-season two-sides-occupied, $\mathrm{CSOO}=$ cold-season one-side-occupied . 
Table 3. Mean $( \pm \mathrm{SE})$ temperature $\left({ }^{\circ} \mathrm{F}\right)$ by period for barn side and time of day. ${ }^{1}$

\begin{tabular}{llll}
\hline $\begin{array}{l}\text { Location and } \\
\text { time of day }\end{array}$ & WSTO & CSTO & CSOO \\
\hline North-side day & $81.92 \pm 0.13^{\mathrm{a}}$ & $29.60 \pm 0.20^{\mathrm{a}}$ & $18.01 \pm 0.23^{\mathrm{b}}$ \\
South-side day & $82.27 \pm 0.13^{\mathrm{a}}$ & $30.83 \pm 0.20^{\mathrm{a}}$ & $20.72 \pm 0.24^{\mathrm{a}}$ \\
North-side night & $68.22 \pm 0.14^{\mathrm{b}}$ & $24.81 \pm 0.21^{\mathrm{b}}$ & $13.23 \pm 0.25^{\mathrm{d}}$ \\
South-side night & $68.70 \pm 0.14^{\mathrm{b}}$ & $25.86 \pm 0.21^{\mathrm{b}}$ & $15.69 \pm 0.26^{\mathrm{c}}$ \\
\hline \multicolumn{2}{c}{ a,b Means within column with different superscripts differ $(P<0.05)}$. \\
\multicolumn{2}{l}{${ }^{1} \mathrm{MDT}=$ mean day temperature, MNT = mean night temperature, WSTO = warm-season two-sides-occupied, } \\
CSTO = cold-season two-sides-occupied, CSOO = cold-season one-side-occupied.
\end{tabular}

Results of the analysis show that temperature differences occur within and between the inside and outside of a naturally ventilated, noninsulated barn (Table 5). Inside and outside mean day and night temperature differences (inside-outside) varied between periods. MDT difference and MNT difference between inside and outside were CSTO $\left(6.27\right.$ and $\left.7.14^{\circ} \mathrm{F}\right)>\operatorname{CSOO}(5.64$ and $\left.5.76^{\circ} \mathrm{F}\right)>\mathrm{WSTO}\left(-0.03\right.$ and $\left.1.32^{\circ} \mathrm{F}\right)(P<0.05)$. WSTO inside and outside mean temperature differences, fell within the range $\left(-0.72\right.$ to $\left.2.16^{\circ} \mathrm{F}\right)$ found by Janni (1999) in another noninsulated barn. The stocking rate on the north-side of $0 \%$ vs. about $75 \%$ appeared to lower the average temperature difference by about $1^{\circ} \mathrm{F}$. Closing the freestall barn during the winter, by raising curtain sidewalls and closing end doors, decreases the removal rate of animal-generated heat, which increases the mean temperature difference between inside and outside during the cold-seasons as compared with the WSTO.

MDT and MNT inside vs. outside differences for $\mathrm{CSOO}$ and CSTO agree with the range 5.4 to $10.8^{\circ} \mathrm{F}$, reported by Bickert and Stowell (1993), Cooper et al. (1998), and Kammel et al. (1982). However, CSTO inside and outside MDT and MNT differences were slightly higher than CSOO and may be partially attributed to higher stocking densities. Cooper, et al. (1998) found inside temperature to increase linearly as stocking density increased. CSTO had stocking densities ranging from 102 to $116 \%$ and 64 to $86 \%$ on the southside and north-side, respectively, while the CSOO had stocking densities of 90 to $100 \%$ and $0 \%$ on the southside and north-side, respectively.
North-side and south-side MDT and MNT differences varied between periods. MDT difference and MNT difference between north-side and south-side were CSOO $\left(-2.71\right.$ and $\left.-2.46^{\circ} \mathrm{F}\right)>\operatorname{CSTO}\left(-1.22\right.$ and $\left.-1.06^{\circ} \mathrm{F}\right)>$ WSTO $\left(-0.36\right.$ and $\left.-0.49^{\circ} \mathrm{F}\right)(P<0.05)$. MDT and MNT differences (north-side-south-side) were less during WSTO than cold seasons CSTO and CSOO. All three periods had slightly lower north-side MDT and MNT.

WSTO MDT difference and CSTO MDT and MNT differences between north-side and south-side fell within the range found by Janni (1999) and Janni (1998), respectively. WSTO north-side and south-side MNT difference was slightly less than the range found by Janni (1999). CSOO north-side and south-side MDT and MNT differences were lower, -2.71 and $-2.46^{\circ} \mathrm{F}$, than the range, -0.72 to $1.8^{\circ} \mathrm{F}$, found by Janni (1998). The difference was attributed to the absence of animals on the north side.

Although MDT and MNT were not different within season for east-end and west-end for the different seasons, MDT and MNT differences between seasons were, but the magnitude of these differences was small. CSTO $\left(-0.34\right.$ and $\left.-0.68^{\circ} \mathrm{F}\right)>\operatorname{CSOO}\left(-0.10\right.$ and $\left.-0.22^{\circ} \mathrm{F}\right)>$ WSTO $\left(0.14\right.$ and $\left.-0.04^{\circ} \mathrm{F}\right)(P<0.05)$.

\section{CONCLUSIONS}

The following conclusions can be drawn from this study: First, inside MDT was higher than outside MDT for both cold periods. The absence of animals on the north side of the barn decreased the average temperature difference between inside and outside approxi-

Table 4. Mean $( \pm \mathrm{SE})$ temperature $\left({ }^{\circ} \mathrm{F}\right)$ by period for barn end and time of day. ${ }^{1}$

\begin{tabular}{llll}
\hline $\begin{array}{l}\text { Location and } \\
\text { time of day }\end{array}$ & WSTO & CSTO & CSOO \\
\hline West-end day & $82.02 \pm 0.13^{\mathrm{a}}$ & $30.38 \pm 0.20^{\mathrm{a}}$ & $19.42 \pm 0.23^{\mathrm{a}}$ \\
East-end day & $82.17 \pm 0.13^{\mathrm{a}}$ & $30.04 \pm 0.21^{\mathrm{a}}$ & $19.32 \pm 0.25^{\mathrm{a}}$ \\
West-end night & $68.48 \pm 0.14^{\mathrm{b}}$ & $25.68 \pm 0.21^{\mathrm{b}}$ & $14.57 \pm 0.25^{\mathrm{b}}$ \\
East-end night & $68.44 \pm 0.14^{\mathrm{b}}$ & $24.99 \pm 0.22^{\mathrm{b}}$ & $14.35 \pm 0.26^{\mathrm{b}}$ \\
\hline \multicolumn{2}{c}{ a,b Means within column with different superscripts differ $(P<0.05)}$. & \\
${ }^{1} \mathrm{MDT}$ = mean day temperature, MNT = mean night temperature, WSTO = warm-season two-sides-occupied, \\
CSTO = cold-season two-sides-occupied, CSOO = cold-season one-side-occupied.
\end{tabular}


Table 5. Mean $( \pm \mathrm{SE})$ differences in temperature $\left({ }^{\circ} \mathrm{F}\right)$ by period for (inside-outside), (north-side-south-side), and (east-end-west-end), and by time of day. ${ }^{1}$

\begin{tabular}{lrrr}
\hline Time of day & \multicolumn{1}{l}{ WSTO } & \multicolumn{1}{l}{ CSTO } & \multicolumn{1}{c}{ CSOO } \\
\hline $\begin{array}{l}\text { Day } \\
\text { (inside-outside) }\end{array}$ & $-0.03 \pm 0.15^{\mathrm{c}}$ & $6.27 \pm 0.15^{\mathrm{a}}$ & $5.64 \pm 0.16^{\mathrm{b}}$ \\
(north-side-south-side) & $-0.36 \pm 0.07^{\mathrm{c}}$ & $-1.22 \pm 0.07^{\mathrm{b}}$ & $-2.71 \pm 0.08^{\mathrm{a}}$ \\
$\quad$ (east-end-west-end) & $0.14 \pm 0.06^{\mathrm{c}}$ & $-0.34 \pm 0.06^{\mathrm{a}}$ & $-0.10 \pm 0.06^{\mathrm{b}}$ \\
Night & & & \\
$\quad$ (inside-outside) & $1.32 \pm 0.15^{\mathrm{c}}$ & $7.14 \pm 0.15^{\mathrm{a}}$ & $5.76 \pm 0.16^{\mathrm{b}}$ \\
(north-side-south-side) & $-0.49 \pm 0.06^{\mathrm{c}}$ & $-1.06 \pm 0.06^{\mathrm{b}}$ & $-2.46 \pm 0.06^{\mathrm{a}}$ \\
(east-end-west-end) & $-0.04 \pm 0.06^{\mathrm{c}}$ & $-0.68 \pm 0.06^{\mathrm{a}}$ & $-0.22 \pm 0.06^{\mathrm{b}}$ \\
\hline
\end{tabular}

a,b,c Means within row with different superscripts differ $(P<0.05)$.

${ }^{1} \mathrm{MDT}$ difference $=$ mean day temperature difference, $\mathrm{MNT}$ difference $=$ mean night temperature difference, WSTO = warm-season two-sides-occupied, CSTO = cold-season two-sides-occupied, CSOO = cold-season oneside-occupied.

mately $1^{\circ} \mathrm{F}$ (day difference $=0.63^{\circ} \mathrm{F}$ and night difference $=1.38^{\circ} \mathrm{F}$ ). Inside MNT was higher than outside for all three periods. Second, the effect of having no cows on one side is shown by the fact that north- and southside MDT and MNT were only different for the CSOO period. South-side MDT and MNT were higher than north-side. The average temperature difference for the north-side during cold seasons was almost $1.5^{\circ} \mathrm{F}$ lower throughout the day than the south-side (day difference $=1.49^{\circ} \mathrm{d}$ night difference $=1.40 \mathrm{~F}^{\circ}$ Third, east and west ends' MDT and MNT were not different for any of the periods.

Results indicate future temperature research, with similar methodology, of naturally ventilated, four-row, noninsulated freestall barns, orientated east to west with curtain sidewalls and both sides occupied, would only need to place a sensor on the north and south side of the barn and outside for both warm- and cold-period studies. Future temperature studies should account for the effect of stocking densities, on temperature differences between sides of the barn and inside vs. outside during different seasons.

\section{ACKNOWLEDGMENTS}

The authors would like to thank Drs. George Shook, David Kammel, and Brian Holmes for their assistance in setting up the analysis and gathering previous re- search. The authors would also like to thank Tom Tabone for his SAS programming assistance. Funding for this research and publication from the USDA Cooperative State Research, Education and Extension Service (CSREES) project WIS01892.

\section{REFERENCES}

Arave, C. W., A. S. Macauly, and N. Russev. 1994. Interaction of dairy cows with facilities and systems. Pages 613-621 in Dairy Systems for the 21st Century. Proc. Third Int. Dairy Housing Conf. ASAE, St. Joseph, MI.

Bickert, W. G., and R. R. Stowell. 1993. Design and operation of natural ventilation systems in dairy free stall barns. Pages 970 977 in Livestock Environment IV. Proc. Fourth Int. Livestock Env. Symp. ASAE, St. Joseph, MI.

Cooper, K., D. J. Parsons, and T. Demmers. 1998. A thermal balance model for livestock buildings for use in climate change studies. J. Agric. Engng. Res. 69:43-52.

Janni, K. A. 1998. Temperature and relative humidity conditions in two freestall dairy barns in northwestern Minnesota. Paper No. 984032 in 1998 ASAE Annual International Meeting, Orlando, Florida.

Janni, K. A. 1999. Summer conditions in two freestall dairy barns in northwestern Minnesota. Paper No. 994008 in 1999 ASAE Annual International Meeting, Toronto, Ontario. Canada.

Kammel, D. W., C. O. Cramer, J. C. Converse, and G. P. Barrington. 1982. Thermal environment of insulated, naturally ventilated dairy barns. Pages 62-71 in Livestock Environment II. Proc. Second Int., Livestock Env. Sym. ASAE, St. Joseph, MI.

SAS 8.0. http://shelf.doit.wisc.edu/SasOnlineDocs/onldoc.htm.

Stowell, R. R., and W. G. Bickert. 1994. Environmental variation in naturally ventilated freestall barns during the warm season. Pages 569-578 in Dairy Systems for the 21st Century. Proc. Third Int. Dairy Housing Conf. ASAE, St. Joseph, MI. 